\title{
HEAVY METAL REMOVAL FROM DREDGING SLURRY USING A PARABOLIC HYDROCYCLONE
}

\author{
Xinghua YANG, Peikun LIU*, Yuekan ZHANG and Lanyue JIANG
}

College of Mechanical and Electrical Engineering, Shandong University of Science and Technology, 266590, China

*Corresponding author: 1pk710128@163.com

(Received May 2018; accepted July 2018)

Key words: heavy metals, parabolic hydrocyclone, CFD, separation efficiency, cut size

\begin{abstract}
Heavy metals usually aggregate as fine particles in dredging slurry and need to be removed or reduced before recycling of the slurry. However, traditional hydrocyclone method often leads to low separation efficiency because of the difficulties in the complete separation of fine particles. To address this problem, this paper proposes a new type of parabolic hydrocyclone for the removal of heavy metals from dredging slurry. The computational fluid dynamics (CFD) software together with mixture and Reynolds stress model (RSM) have been used to simulate the internal flow field of the parabolic hydrocyclone, which was then verified with experimental tests. The simulation results show that, compared with traditional hydrocyclones, the flow field inside the parabolic hydrocyclone is more stable, which effectively help to avoid the mixture of coarse and fine particles caused by the flow field disturbance. Further experimental results demonstrate that the cumulative percentage of fine particles in the underflow product decreases. The cut size increases from $30 \mu \mathrm{m}$ to $49 \mu \mathrm{m}$ and the steepness index rises from 0.13 to 0.2 , which proves that the separation accuracy can be improved, and the fine particles mixed in the underflow can be removed effectively. Moreover, the recovery rate of heavy metalas $\mathrm{Zn}$ and $\mathrm{Cr}$ in the overflow products reaches $97.21 \%$ and $78.27 \%$, respectively, verifying the enrichment effect. Therefore, after the parabolic hydrocyclone separation process, the underflow products contain less heavy metals and become both non-hazardous and recyclable.
\end{abstract}

Palabras clave: metales pesados, hidrociclón parabólico, CFD, eficiencia de separación, tamaño de corte

\section{RESUMEN}

Los metales pesados usualmente se agrupan como partículas finas en los lodos dragados y necesitan ser removidas o reducidas antes de reciclar el lodo. Sin embargo, el método tradicional del hidrociclón con frecuencia lleva una eficiencia de separación baja debido a las dificultades para lograr la separación de las partículas finas. Para resolver este problema, este artículo propone un nuevo tipo de hidrociclón parabólico para remover metales pesados durante el dragado de los lodos finos. Para simular el campo del flujo interno del hidrociclón parabólico, que después fue verificado con pruebas experimentales, se utilizaron la dinámica de fluídos computacional (CFD, por sus siglas en inglés) junto con el modelo de mezcla y el modelo de estrés de Reynolds (RSM). Los resultados 
de la simulación muestran que, al comparar con hidrociclones tradicionales, el campo del flujo dentro del hidrociclón parabólico es más estable, lo que efectivamente ayuda a evitar la mezcla de partículas gruesas y finas causada por las perturbaciones en el campo del flujo. Motros resultados experimentales demostraron que el porcentaje acumulado de partículas finas en el flujo de fondo disminuye. El tamaño de corte se incrementa de $30 \mu \mathrm{m}$ a $49 \mu \mathrm{m}$ y el índice de la pendiente se eleva de 0.13 a 2.2, lo que prueba que la la exactitud de la separación se puede incrementar y que las partículas finas mezcladas en el flujo de fondo se pueden remover de forma efectiva. Más aún, la tasa de recuperación de los metales pesados $\mathrm{Zn}$ y $\mathrm{Cr}$ en los productos del flujo de fondo alcanza el $97.21 \%$ y el $78.27 \%$, respectivamente, verificando el efecto de enriquecimiento. Por lo tanto, después del proceso de separación por el hidrociclón parabólico, lo productos del flujo de fondo mcho menos metales pesados y son tanto no peligrosos como reciclables.

\section{INTRODUCTION}

River sediment pollution is becoming an increasingly prominent environmental problem due to the direct or substandard discharge of industrial wastewater. What's worse, the sediment usually contains heavy metals such as zinc, chromium, lead, etc. During the process of river dredging, a large amount of dredging slurry is piled up along the river shore (Yang et al. 2017, Hanedar et al. 2017, Teng and Zhou 2017), which releases the heavy metals contained to the soil with the aid of longterm rainwash, which makes secondary pollution to surrounding soil and environment inevitable (Cui et al. 2006, Olatuyi et al. 2014, Shahrabi et al. 2014, Bian and Yang 2017, Usman et al. 2017). Therefore, it is urgently needed to seek a kind of economical and feasible technology to remove the heavy metals in dredging sediment (Usman et al. 2017, Mi et al. 2016, Rehman et al. 2017).

Hydrocyclone separation technology has been widely used in mining, environmental and chemical engineering processes for its advantages including low maintenance costs, low energy consumption and large handling capacity (Shadrunova and Orekhova 2015, Ghodrat and Kuang 2016, Otto et al. 2016, Emelue and Omonzogbe 2018). Recently, some researchers began to study the application of this technology in the removal of heavy metals (Yang et al. 2018, Grzeczka and Szymak 2016, Kumruzzaman and Sarker 2017). For example, Bhaskar reported that a hydrocyclone was capable of separating fine particles rich in $\mathrm{Pb}$ and $\mathrm{Zn}$ from lead-zinc ore (Bhaskar et al. 2005, Sharma and Yadav 2017). Park adopted the hydrocyclone technology to reduce contaminated dredged material (Park et al. 2006, Ramezani et al. 2017). Sierra used hydrocyclones to treat the grain-size fraction below $125 \mu \mathrm{m}$ for contaminated soil (Sierra et al. 2010, Fu and Liu 2017). Ko studied the recycling of fly ash using a dense-medium hydrocyclone separation process (Ko et al. 2013, Kumar 2017, Halin et al. 2017, Zaidi et al. 2017). However, for the traditional hydrocyclone separation, a common problem is the mixture of fine particles in the underflow products, thus affecting the separation accuracy and product quality. The main cause lies in the unstable flow field near the bottom of the hydrocyclone (Tariq et al. 2017). The flow disturbance makes some fine granules, flowing into the inner spiral flow after the initial separation, enter into the outer spiral flow again and mix with the coarse particles (Singh et al. 2018, Danielson et al. 2016, Kylili et al. 2018). At the area near the underflow, this phenomenon is more evident due to a high concentration of solid particle aggregation. Hence, more and more researches have focused on the problem and put emphasis on how to reduce fine particles in the underflow (Dueck et al. 2010, Hwang and Chou 2017, Ghodrat et al. 2014, Minkov et al. 2011, Farghaly et al. 2010).

Therefore, this paper put forward a new type of parabolic hydrocyclone aiming at the improvement of separation efficiency (Yasin and Usman 2017). By changing the conventional linear cone into parabolic structure, the separation space could be enlarged effectively, and the internal flow field became more stable so as to remove the fine particles mixed in the underflow (Vazdani et al. 2017). In order to achieve a comprehensive understanding of the internal flow field characteristics and the separation performance, the numerical and experimental study on parabolic hydrocyclone were carried out. The Computational Fluid Dynamics (CFD) software was used to analyse the flow field, and then an experimental platform was set up to verify the enrichment effect of heavy metals. 


\section{NUMERICAL SIMULATION}

\section{Structure of the parabolic hydrocyclone}

The conical section is the main separation area in a hydrocyclone and whether its structure is reasonable is crucial to the improvement of separation efficiency (Zhang et al. 2011, Tang et al. 2015, John et al. 2017). According to previous studies, the analytical solution of axial velocity inside the hydrocyclone is:

$U_{a}=\frac{1}{2} B\left(3 \alpha-\frac{5 r}{z}\right) \frac{1}{r^{\frac{1}{2}}}$

Where $U_{\mathrm{a}}$ is axial velocity, $B$ is constant, $\alpha$ is halfcone angle, $z$ is height of cross section, $r$ is rotational radius. It is obvious that if other parameters remain unchanged, $U_{\mathrm{a}}$ will decrease with the increase of $r$, which is consistent with the purpose of changing a linear cone to a parabolic cone. As shown in Fig. 1, the increased radius can reduce the axial velocity of fluid and extend the residence time of particles (Farajollahi and Delavar 2017). Also, the enlargement of separation space is conducive for particles to stay longer, meaning that a more sufficient separation process is obtained even in the bottom section. As a result, less fine particles flow into the underflow, and thus the separation efficiency can be improved. In

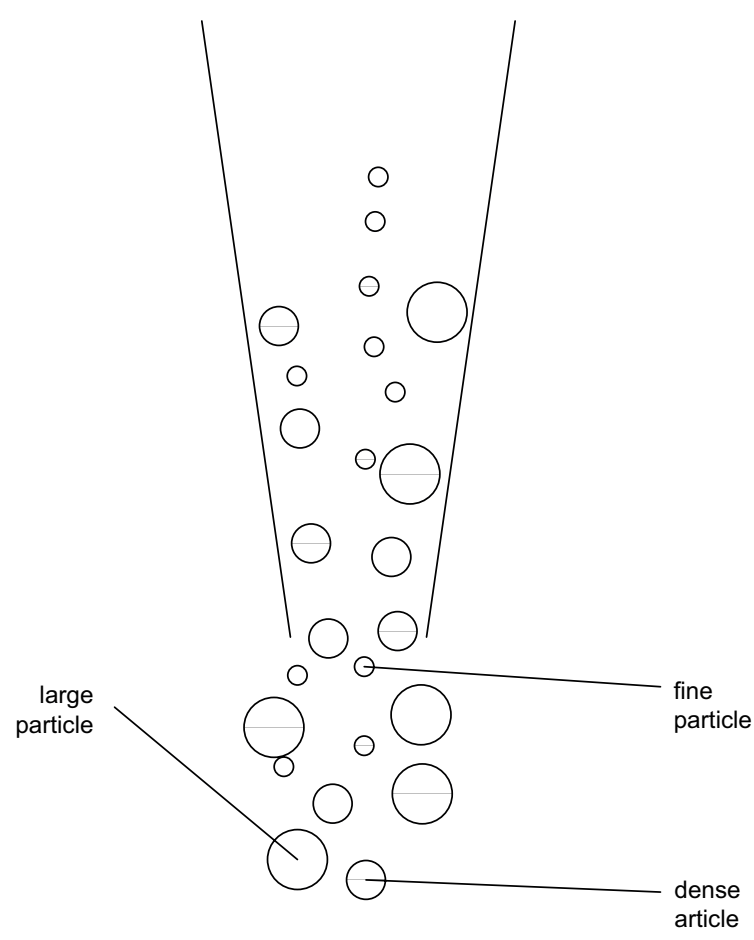

(a) Linear cone addition, the parabolic structure makes the inner wall smoother, which can not only stabilize the internal flow field, but also decrease the frictional resistance caused by boundary layer separation. Therefore, the energy consumption and pressure drop can be reduced effectively.

The two kinds of hydrocyclone have been designed with the main structural parameters listed in Table I. The profile of the inner wall of parabolic hydrocyclone conforms to a cubic parabola curve. To facilitate the comparison, the height and diameter of them were defined as the same. The 3D models of the flow field region in the hydrocyclone were built using software SolidWorks, as shown in Fig. 2. Then they were imported into ICEM and the structural hexahedron mesh generation technology was used to mesh them.

\section{Boundary conditions and solver setup}

To compare the separation performance, a solid-liquid two-phase numerical simulation of the traditional and parabolic hydrocyclones has been conducted with Fluent 14.5, in which the Mixture model was chosen as the multiphase flow model and RSM model as the turbulence model. The materials are composed of water, $\mathrm{SiO}_{2}$ and $\mathrm{Fe}_{2} \mathrm{O}_{3}$ so as to simulate

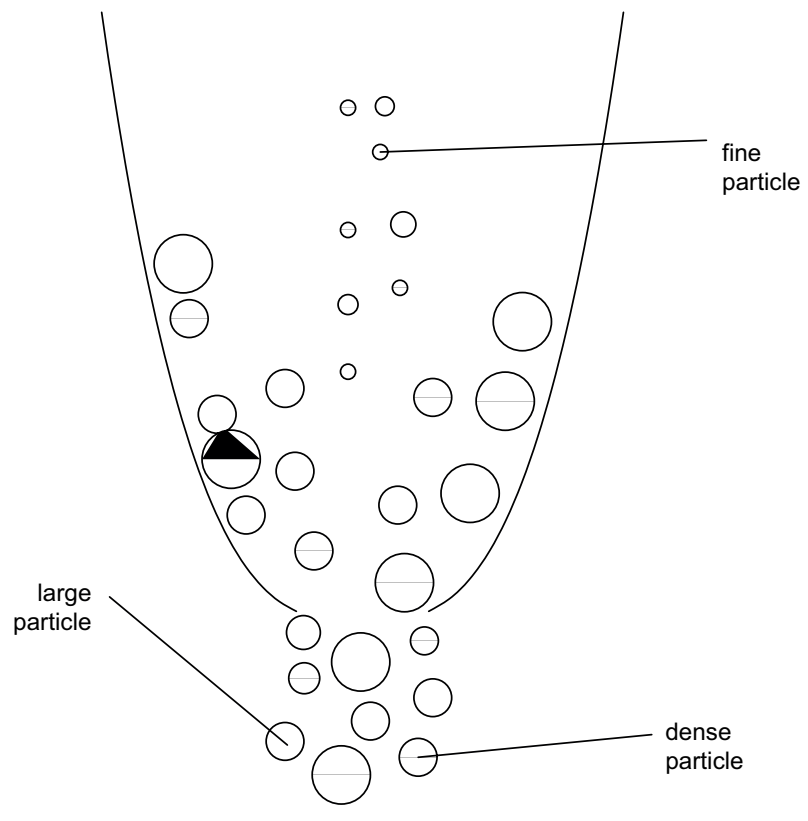

(b) Parabolic cone

Fig. 1. Schematic diagram of particle motion in conical section 
TABLE I. STRUCTURAL PARAMETERS OF HYDROCYCLONE

\begin{tabular}{cccccc}
\hline $\begin{array}{c}\text { Cylinder } \\
\text { diameter/mm }\end{array}$ & $\begin{array}{c}\text { Cylinder } \\
\text { length } / \mathrm{mm}\end{array}$ & $\begin{array}{c}\text { Inlet } \\
\text { dimension } / \mathrm{mm}\end{array}$ & $\begin{array}{c}\text { Vortex finder } \\
\text { diameter } / \mathrm{mm}\end{array}$ & $\begin{array}{c}\text { Insert depth of } \\
\text { vortex finder/mm }\end{array}$ & $\begin{array}{c}\text { Spigot } \\
\text { diameter/mm }\end{array}$ \\
\hline 50 & 8 & $20 \times 9.5$ & 15 & 50 & 8 \\
\hline
\end{tabular}

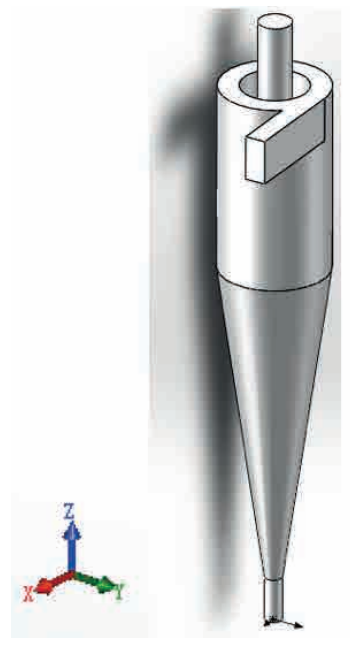

(a) Traditional

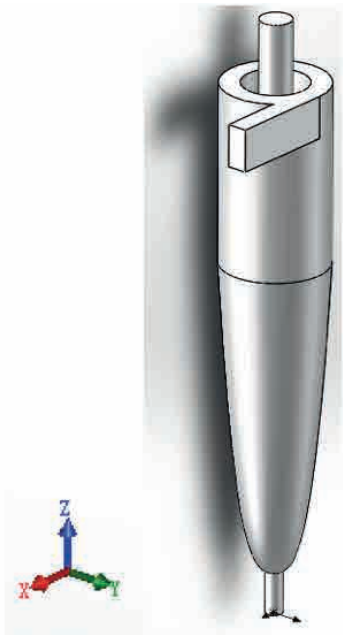

(b) Parabolic
Fig. 2. 3D model of the hydrocyclone

mixed solid particles of different sizes and densities. The density of $\mathrm{SiO}_{2}$ and $\mathrm{Fe}_{2} \mathrm{O}_{3}$ are $2650 \mathrm{~kg} / \mathrm{m}^{3}$ and $5240 \mathrm{~kg} / \mathrm{m}^{3}$, respectively. The particle size distribution is listed in Table II. The feed inlet is set as velocity-inlet and the value is $5.26 \mathrm{~m} / \mathrm{s}$ for both the water and particle phase. The overflow and underflow outlet are set as as pressure-outlet and the pressure is atmospheric pressure. The SIMPLE algorithm is adopted as the coupling method of pressure and velocity. The discretization format for pressure and other governing equations is PRESTO and QUICK, respectively.

\section{Simulation results and analysis}

The plane $\mathrm{x}=0$ and different cross section, including $\mathrm{z}=50 \mathrm{~mm}$ (near to the bottom), and $\mathrm{z}=100 \mathrm{~mm}$ (middle of the conical section) was chosen, and the simulation results were analysed.

\section{Tangential velocity}

The tangential velocity is the main factor that affects the solid-liquid separation (Nema et al. 2017). Fig. 3 shows the representative tangential velocity distribution in different cross sections of the two types of hydrocyclones. Both of their tangential velocity distribution curves show good symmetry and the same change tendency. An " $M$ " curve can be observed along the radius. From the central axis to the wall, the tangential velocity first increases sharply, then as it reaches the peak point, begins to decrease, and eventually becomes zero at the inner wall.

Moreover, the radial position where the maximum tangential velocity appears is nearly the same. But for the parabolic hydrocyclone, the maximum value is slightly lower. This is beneficial for preventing fine particles from entering the outer spiral flow under the action of high centrifugal force field (Yun et al. 2017). It should also be noticed that, after it reaches its maximum value, the decrease speed of the tangential velocity is slower than that of the traditional type. This indicates that the flow field in the parabolic section becomes more stable, therefore avoiding particles mixture caused by the flow field disorder and reducing fine granules in the underflow.

\section{Axial velocity and LZVV}

The axial velocity of fluid affects the residence time of particles to a great extent. Inside the hydrocyclone, all the points representing zero axial velocity form a LZVV, which is an interface. The fluid inside it flows upward and forms the inner spiral flow, reversely, the fluid outside flows downward and forms

TABLE II. PARTICLE SIZE DISTRIBUTION

\begin{tabular}{lcccccccc}
\hline Size $(\mu \mathrm{m})$ & 1 & 5 & 10 & 20 & 30 & 40 & 50 & Total \\
\hline Content $(\%)$ & 20 & 25 & 15 & 15 & 10 & 10 & 5 & 100 \\
Volume fraction of $\mathrm{SiO}_{2}(\%)$ & 1.133 & 1.417 & 0.85 & 0.85 & 0.567 & 0.567 & 0.283 & 5.6 \\
Volume fraction of $\mathrm{Fe}_{2} \mathrm{O}_{3}(\%)$ & 0.567 & 0.708 & 0.425 & 0.425 & 0.283 & 0.283 & 0.142 & 2.8 \\
\hline
\end{tabular}




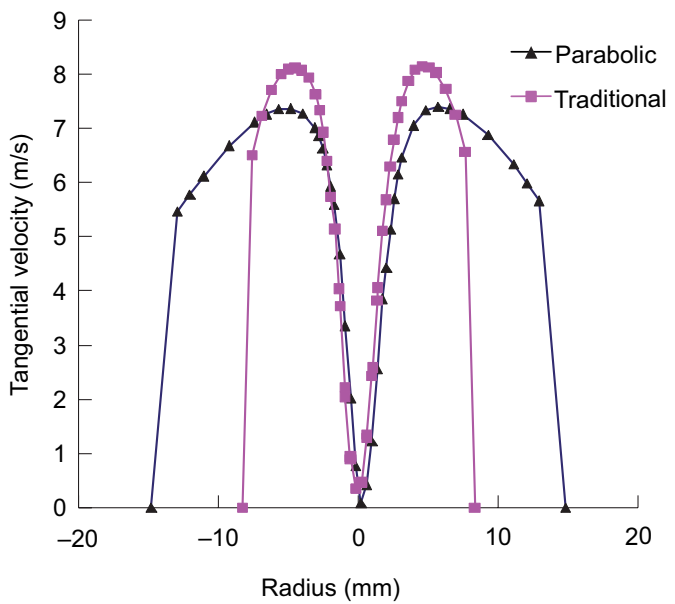

(a) $z=50$

Fig. 3. Tangential velocity in different cross sections

the outer spiral flow. Small and light particles can be easily carried by the inner spiral flow and migrate to overflow while large and dense particles follow the outer spiral flow and enter into the underflow. Fig. 4 compares the axial velocity in different cross sections. For the parabolic hydrocyclone, the axial velocity of the outer spiral flow decreases while that of the inner spiral flow increases. The benefits include: on the one hand, the reduced axial flow motion prolongs the residence time and enables more thorough separation for coarse and fine particles; on the other hand, the increasing inner flow motion makes fine particles enter into the vortex finder rapidly and lowers their possibility to mix with the underflow.

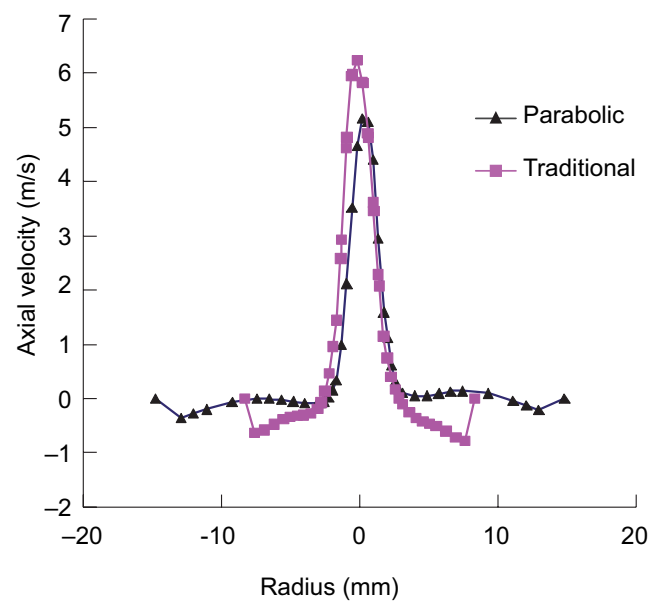

(a) $z=50$

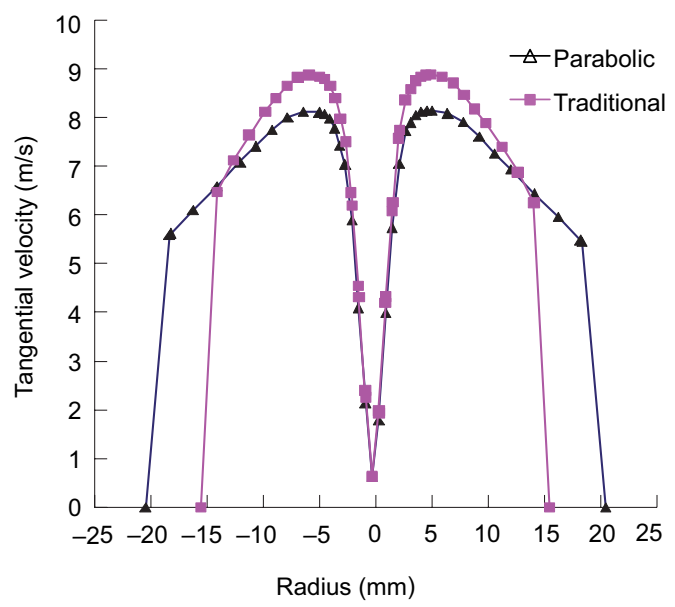

(b) $z=100$
The contours of LZVV can be inferred as shown in Fig. 5. It is obvious that the LZVV of parabolic hydrocyclone moves outward, facilitating more fine particles be encompassed by the inner spiral flow. Moreover, the LZVV in the traditional hydrocyclone distorts near the bottom, which may result in flow field disturbance and make well-separated particles to again become chaotic. But in the parabolic hydrocyclone, multiple zero points of axial velocity exist in the same cross section, forming a cyclic flow. The existence of the circulation flow produces a similar "washing effect", which can force the mixed fine particles to go back into the inner flow so as to strengthen the sorting process. Consequently, the separation accuracy is improved.

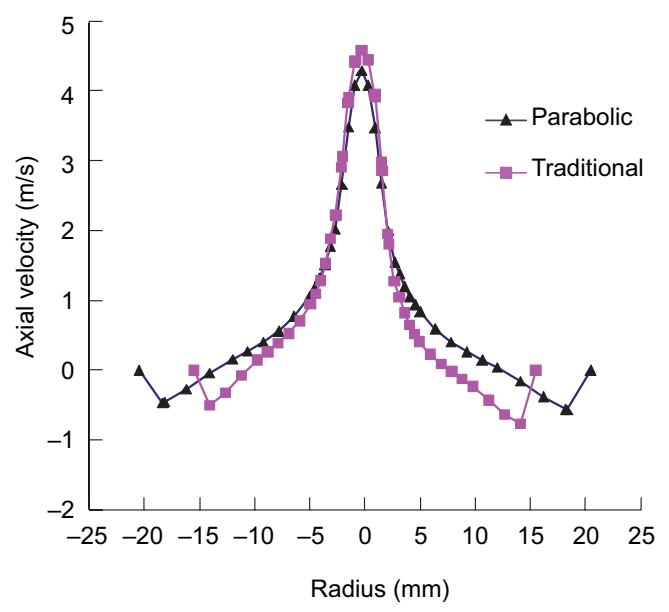

(b) $z=100$

Fig. 4. Axial velocity at different cross section 


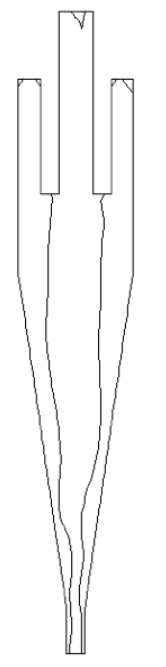

(a) Traditional

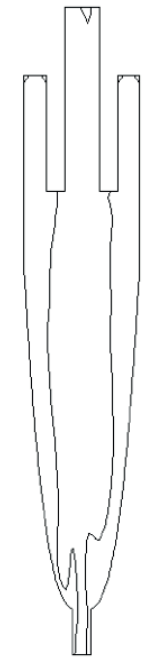

(b) Parabolic

Fig. 5. Contours of LZVV

\section{Radial velocity}

Fig. 6 provides the comparison of radial velocity in different cross sections. At the main separation area, for example $\mathrm{z}=100$, the radial velocity of fluid in the parabolic hydrocyclone is higher than that in the traditional hydrocyclone, which promotes the radial movement of particles and further separation. But in the cross section near the bottom, where $\mathrm{z}=50$, the radial velocity becomes lower in the parabolic hydrocyclone. Actually, at this moment the separation process has finished basically. The low radial velocity gradient is conducive to the formation of

a suspended high-density layer and can prevent fine particles from passing through the suspended layer.

\section{Density distribution}

Fig. 7 represents the density distribution inside the traditional and parabolic hydrocyclone. It can be seen that, under the action of the centrifugal force, the solid particles distribute orderly along the radial and axial direction according to their density and particle size. The density increases gradually along the central axis to the wall, as well as along the vortex finder to the spigot. In the traditional

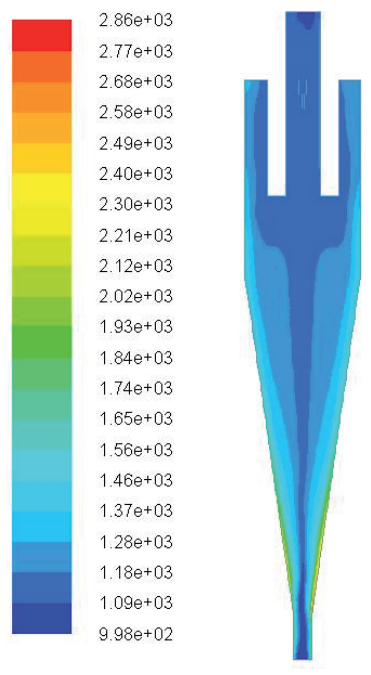

(a) Traditional

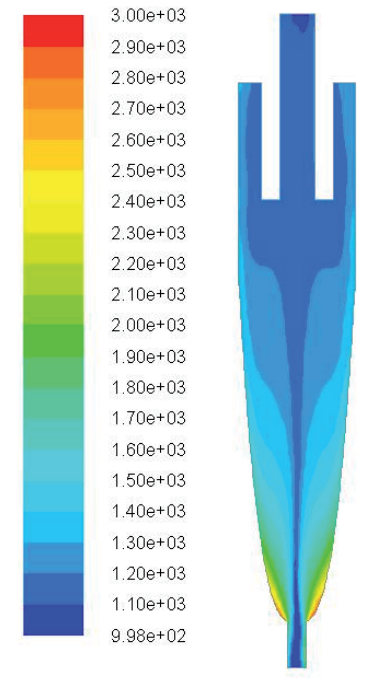

(b) Parabolic
Fig. 7. Contours of density distribution

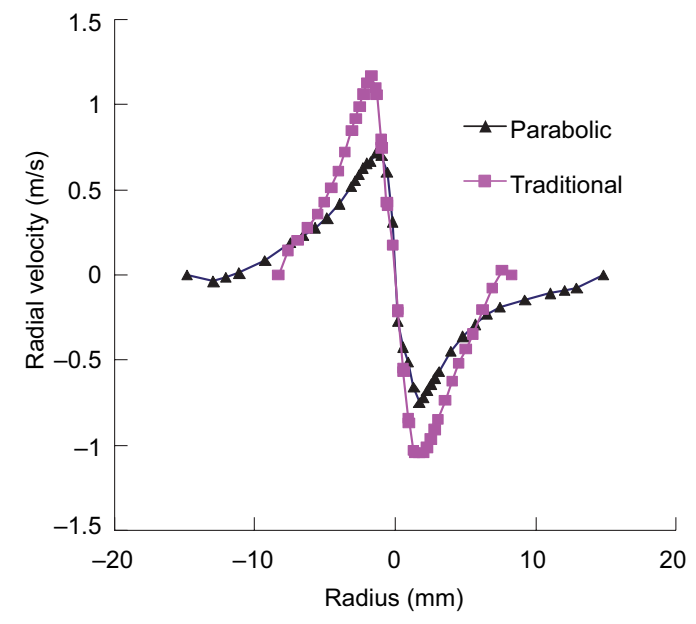

(a) $z=50$

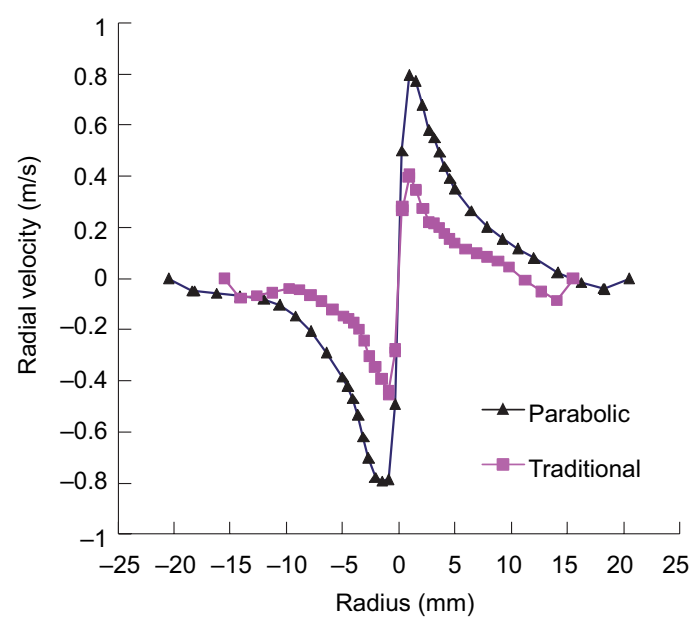

(b) $z=100$

Fig. 6. Radial velocity in different sections 
TABLE III. YIELD AND RECOVERY RATE (UNDERFLOW)

\begin{tabular}{lcccc}
\hline $\begin{array}{l}\text { Type of } \\
\text { hydrocyclone }\end{array}$ & $\begin{array}{c}\text { Yield of solid } \\
\text { phase (\%) }\end{array}$ & $\begin{array}{c}\text { Recovery rate of } \\
\mathrm{SiO}_{2} 5 \mu \mathrm{m}(\%)\end{array}$ & $\begin{array}{c}\text { Recovery rate of } \\
\mathrm{Fe}_{2} \mathrm{O}_{3} 5 \mu \mathrm{m}(\%)\end{array}$ & $\begin{array}{c}\text { Content of } \\
\mathrm{Fe}_{2} \mathrm{O}_{3}(\%)\end{array}$ \\
\hline traditional & 35.44 & 5.34 & 8.04 & 60.37 \\
parabolic & 32.33 & 4.54 & 6.08 & 62.09 \\
\hline
\end{tabular}

hydrocyclone, along the radial direction, a series of equivalent density layers are formed, appearing as cones with larger cone angles than that of the hydrocyclone. The outer spiral flow outside the density layers enters into the spigot directly in the conical section. By contrast, for the parabolic hydrocyclone, the particles move slowly at the bottom due to the gentle wall curve, and then gradually form a rotating high-density suspension layer. In this way, small particles with lower density than the suspension layer can hardly pass through it and flow back to the inner flow under the action of circulating eddy current, while dense and coarse particles with bigger density pass through the suspension layer and flow toward the spigot. That is, the parabolic hydrocyclone obtains certain sorting effect.

\section{Fine particle distribution}

Fig. 8 illustrates the comparison of $5 \mu \mathrm{m}$ particle distribution in both the traditional and the parabolic hydrocyclone. It is obvious that the $5 \mu \mathrm{m}$ particles concentrated in the conical section. When taking into

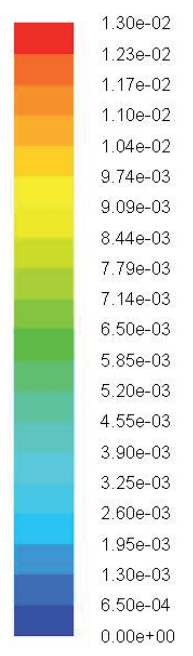

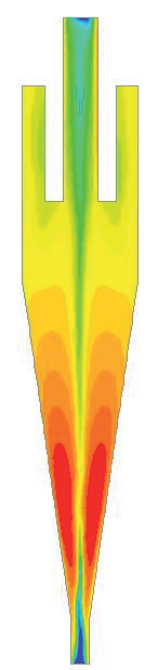

(a) Traditional
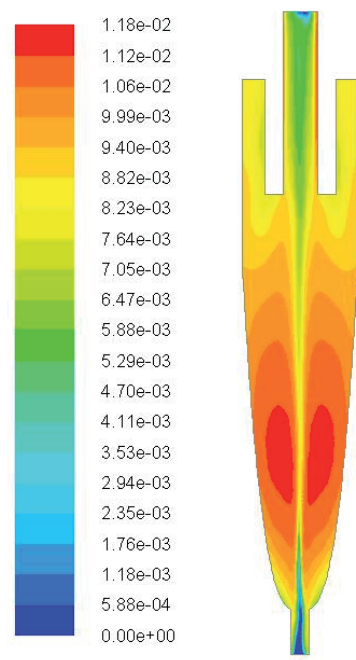

(b) Parabolic
Fig. 8. Contours of $5 \mu \mathrm{m}$ particles concentration consideration the LZVV distribution (Fig. 5), it can be inferred that for the traditional hydrocyclone, the high concentration area covers both the inner spiral flow and the outer spiral flow, which means some fine particles may enter into the underflow following the outer spiral flow. However, this phenomenon can be improved in the parabolic hydrocyclone. From Fig. 8 (b), the $5 \mu \mathrm{m}$ particles concentrate area is bigger and its position nearer to the direction towards overflow pipe. Therefore, it increases the possibility of fine particles entering into the overflow, reducing the mixture of them in the underflow.

\section{Separation performance}

The simulated yield and recovery rate of the underflow is listed in Table III. The yield of the solid phase in the underflow of the parabolic hydrocyclone is reduced to $32.33 \%$ compared with the traditional type $(35.44 \%)$, attributing to the extension outside of LZVV and the increase of axial velocity of inner spiral flow. Moreover, due to the enlargement of separation space and stable flow field, the content of fine particles in the underflow is reduced obviously. The recovery rate of $5 \mu \mathrm{m} \mathrm{SiO}_{2}$ particles and $\mathrm{Fe}_{2} \mathrm{O}_{3}$ decrease by $14.98 \%$ and $24.38 \%$, respectively. Finally, the decrease of fine particles leads to an effective content increase of the dense phase $\mathrm{Fe}_{2} \mathrm{O}_{3}$, from $60.37 \%$ to $62.09 \%$. The data of the parabolic hydrocyclone illustrate the effectiveness of the sorting process.

\section{EXPERIMENTS OF HEAVY METALS REMOVAL}

\section{Experiment plan}

The experiments were carried out at Yishui River. A bypass from the main pipeline of the dredging system was set up and the feeding slurry was processed with the two types of hydrocyclone. The feed pressure was controlled by a pressure valve. Fig. 9 gives the photograph of the experimental apparatus on site. In the experiment, the solid concentration of the feeding slurry remain constant $(9.87 \%$ weight $)$. 


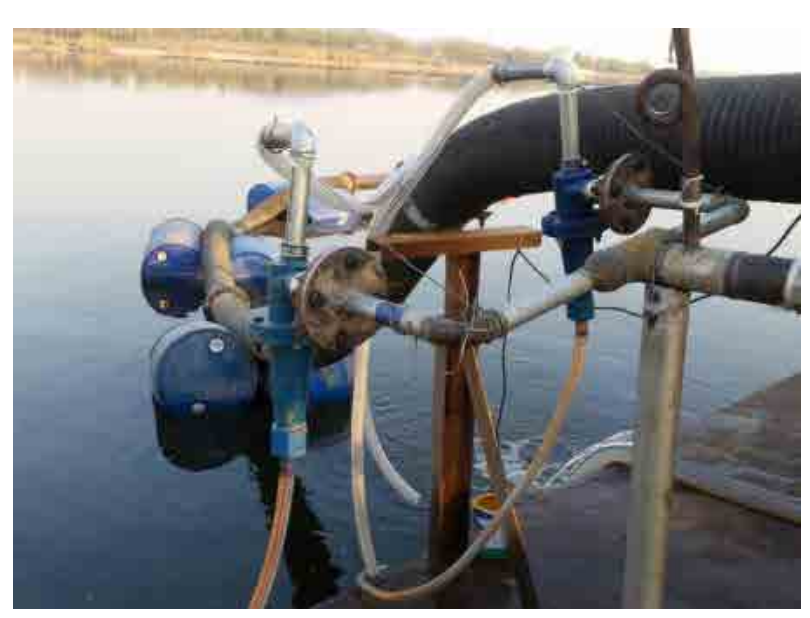

Fig. 9. Experimental apparatus on site

After reaching a stationary regime, samples from the overflow and underflow were taken in flasks. They were then weighed and dried in an oven to obtain dry weight and representative samples for laser particle analyzer (BT9300-S). Besides, samples were also prepared for heavy metal grade test (IPE-AES method).

\section{Cut size and separation accuracy}

Table IV compares the fine particles content in overflow and underflow. For the parabolic hydrocyclone, the concentration of particles smaller than $10 \mu \mathrm{m}$ in the underflow decreases from $12.69 \%$ to $10.63 \%$, and that of particles smaller than $20 \mu \mathrm{m}$ decreases from $26.61 \%$ to $21.74 \%$. It can be concluded that fine granules in the underflow products are reduced effectively.

With material balancing calculation, the size distribution was obtained, and the grading efficiency curve was plotted later. As shown in Fig. 10, the cut size $\mathrm{d}_{50}$ of the parabolic and traditional hydrocyclone is $49 \mu \mathrm{m}$ and $30 \mu \mathrm{m}$, respectively. It is clear that the cut size increases thanks to less fine particles in the underflow.
The separation accuracy is often expressed by steepness index, which can be calculated by,

$S_{I}=\frac{d_{25}}{d_{75}}$

Where, $\mathrm{d}_{25}$ and $\mathrm{d}_{75}$ represent particle size corresponding to $25 \%$ and $75 \%$ in the efficiency curve.

From Fig. 10, for the traditional hydrocyclone, $\mathrm{d}_{75}=90 \mu \mathrm{m}, \mathrm{d}_{25}=12 \mu \mathrm{m}$, while for the parabolic hydrocyclone, $\mathrm{d}_{75}=105 \mu \mathrm{m}, \mathrm{d}_{25}=21 \mu \mathrm{m}$. It can be calculated that their steepness index is $\mathrm{S}_{\mathrm{I}}=0.13$ and $\mathrm{S}_{\mathrm{I}}=0.2$, respectively. Thus the separation accuracy is improved.

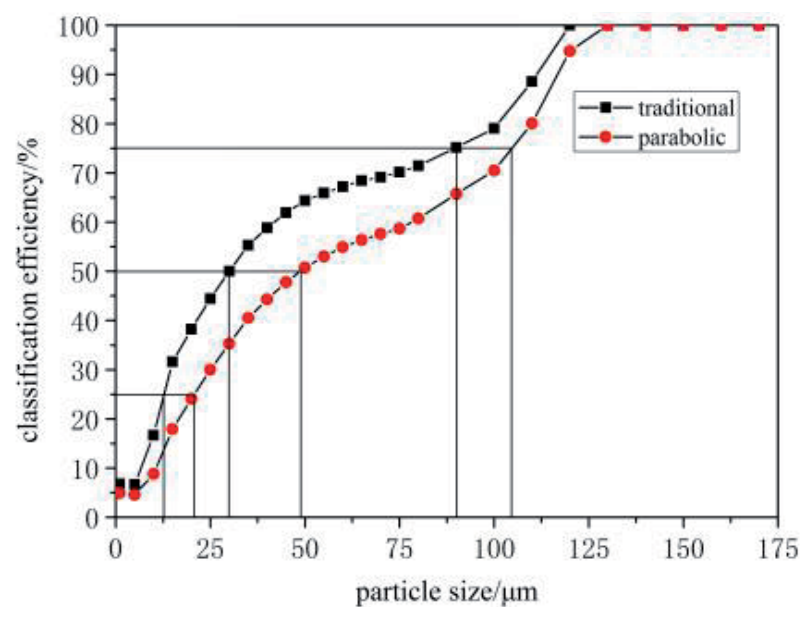

Fig. 10. Grading efficiency curve

\section{Heavy metals enrichment}

The metal recovery is defined as the percentage of the total elements contained in the overflow with respect to that in the feed slurry. For the parabolic hydrocyclone, the concentration of feed, overflow and underflow is $9.87 \%, 5.46 \%$ and $56.66 \%$, respectively according to the experimental data. The underflow yield is $49.45 \%$. Table $\mathbf{V}$ gives the grade of heavy metals $\mathrm{Zn}$ and $\mathrm{Cr}$ in the feed, outflow and

TABLE IV. PARTICLES CONTENT IN UNDERFLOW AND OVERFLOW

\begin{tabular}{ccccccc}
\hline \multirow{2}{*}{ Particle size/ $\mu \mathrm{m}$} & Feed/\% & \multicolumn{2}{c}{ Traditional hydrocyclone } & & \multicolumn{2}{c}{ Parabolic hydrocyclone } \\
& & Underflow /\% & Overflow /\% & & Underflow /\% & Overflow /\% \\
\hline-5 & 37.23 & 7.34 & 50.06 & & 6.87 & 44.85 \\
-10 & 48.20 & 12.69 & 63.06 & & 10.63 & 57.58 \\
-20 & 61.94 & 26.61 & 77.25 & & 21.74 & 72.99 \\
-30 & 71.52 & 39.75 & 85.33 & & 33.83 & 82.25 \\
\hline
\end{tabular}


underflow. For example, the grade of $\mathrm{Zn}$ is $250 \mathrm{~g} / \mathrm{t}$ in the overflow while only $31 \mathrm{~g} / \mathrm{t}$ in the underflow. Compared with that of the feed slurry, its recovery rate in the overflow reaches $97.21 \%$. Also, the grade of $\mathrm{Cr}$ is $480 \mathrm{~g} / \mathrm{t}$ in the overflow while only $130 \mathrm{~g} / \mathrm{t}$ in the underflow and its recovery rate is $78.27 \%$. It is verified that after the separation by the parabolic hydrocyclone, most heavy metals have been enriched in the overflow effectively.

TABLE V. GRADE OF HEAVY METALS IN FEED, OVERFLOW AND UNDERFLOW

\begin{tabular}{ccccc}
\hline & $\begin{array}{c}\text { Feed } \\
\mathrm{g} / \mathrm{t}\end{array}$ & $\begin{array}{c}\text { Overflow } \\
\mathrm{g} / \mathrm{t}\end{array}$ & $\begin{array}{c}\text { Underflow } \\
\mathrm{g} / \mathrm{t}\end{array}$ & $\begin{array}{c}\text { Recovery } \\
\text { in overflow \% }\end{array}$ \\
\hline $\mathrm{Zn}$ & 130 & 250 & 31 & 97.21 \\
$\mathrm{Cr}$ & 310 & 480 & 130 & 78.27 \\
\hline
\end{tabular}

\section{CONCLUSIONS}

A new type of parabolic hydrocyclone has been proposed for the removal of heavy metals from the dredging slurry. The Mixture and RSM model in CFD software are adopted to simulate its internal flow field and its separation performance is analysed both by numerical simulation and experimental tests. Some conclusions can be drawn as follows:

(1) Compared with the traditional hydrocyclone, the flow field inside the parabolic hydrocyclone is more stable, which effectively prevents the coarse and fine particles from mixing due to the flow field disturbance.

(2) The tangential velocity of fluid in the parabolic hydrocyclone is lower than that in the conventional type, but its distribution curve changes gently. More residence time for thorough particles separation is obtained due to the decrease of axial velocity of the outer spiral flow. More fine particles can move to the overflow rapidly thanks to the increase of axial velocity of inner spiral flow.

(3) The simulated yield and recovery rate of underflow show that certain sorting effect can be obtained in the parabolic hydrocyclone, which can be attributed to the extension of LZVV and the formation of suspended high-density layer.

(4) Distinct enrichment effect for heavy metal in dredging slurry is found by use of parabolic hydrocyclone separation. The recovery rate of heavy metal $\mathrm{Zn}$ and $\mathrm{Cr}$ in the overflow products is $97.21 \%$ and $78.27 \%$, respectively.

\section{ACKNOWLEDGMENTS}

This study was supported by the National Natural Science Foundation of China (Funding No. $\mathrm{x} 21276145$ ) and Natural Science Foundation of Shandong Province (Funding No. ZR2016EEM37).

\section{REFERENCES}

Bhaskar K., Govindarajan B., Barnwal J., Rao K.K., Gupta B.K. and Rao T.C. (2005). Classification studies of lead-zinc ore fines using water-injection cyclone. International Journal of Mineral Processing, 77 (2), 80-94.

Bian B. and Yang, D. (2017). Distribution of heavy metals in raw and anaerobically digested pig slurry: a fullscale study in Taihu basin, China. Desalination and Water Treatment. 63, 145-151.

Cui H., Loretta Y. and Grace J. (2006). Exploration of remediation of acid rock drainage with clinoptilolite as sorbent in a slurry bubble column for both heavy metal capture and regeneration. Water Research. 40 (18), 3359-3366.

Danielson J.J., Poppenga S.K., Brock J.C., Evans G.A., Tyler D.J., Gesch D.B., Thatcher C.A. and Barras J.A. (2016). Topobathymetric Elevation Model Development using a New Methodology: Coastal National Elevation Database. Journal of Coastal Research. (76), 75-89.

Dueck J., Pikushchak E., Minkov L., Farghaly M. and Neesse T.H. (2010). Mechanism of hydrocyclone separation with water injection. Minerals Engineering. 23 (4), 289-294.

Emelue G.U. and Omonzogbe E.A. (2018). Growth Performance of African Giant Land Snails (Archachatina Marginata) Fed with Feed Formulated with Different Calcium Sources. Malaysian Journal of Sustainable Agriculture. 2(1), 1-4.

Farajollahi G. and Delavar M.R. (2017). Assessing accident hotspots by using volunteered geographic information. Journal CleanWAS. 1 (2), 14-17.

Farghaly M., Golyk V., Ibrahim G.A., Ahmed M.M. and Neesse T.H. (2010). Controlled wash water injection to the hydrocyclone underflow. Minerals Engineering. 23 (4), 321-325.

Fu H.L. and Liu X.J. 2017. Research on the Phenomenon of Chinese Residents' Spiritual Contagion for the Reuse of Recycled Water Based on SC-IAT. Water. 9 (11), 846 . 
Ghodrat M., Kuang S., Yu A.B., Vince A., Barnett G.D. and Barnett P.J. (2014). Numerical analysis of hydro cyclones with different conical section designs. Minerals Engineering. 62 (7), 74-84.

Ghodrat M., Qi Z. and Kuang S. (2016). Computational investigation of the effect of particle density on the multiphase flows and performance of hydro cyclone. Mineral Engineering. 90, 55-69

Grzeczka G., Szymak P. (2016). The hardware implementation of demonstrator air independent electric supply system based on pem fuel cell. Polish Maritime Research. 23 (4), 84-92.

Halin N.I.A., Huyop F., Hamid H.A., Halim K.B.A. and Hamid A.A.A. (2017). In silico binding interactions of dehalogenase (Dehe) with various haloalkanoic acids. Science Heritage Journal. 1(1), 04-06.

Hanedar A., Güneş E., Kaykioğlu G. and Cabi E. (2017). Determination of polychlorinated biphenils in the soil, atmospheric deposition and bioindicator samples in the meric-ergene river basin,Turkey. Acta Scientifica Malaysia. 1(1), 13-15.

Hwang K. and Chou S. (2017). Designing vortex finder structure for improving the particle separation efficiency of a hydrocyclone. Separation and Purification Technology. 172, 76-84.

John A., Hassan B., Hanisa S.N., Kamaruzzaman M., Kadhar Sha B.Y. (2017). Community structure and post-monsoonal distribution of icthyoplankton in Kuatan river, Malaysia. Environment Ecosystem Science. 1 (1), 01-03.

Ko M., Chen Y. and Wei P. (2013). Recycling of municipal solid waste incinerator fly ash by using hydrocyclone separation. Waste Manage. 33 (3), 615-620.

Kumar D. 2017. Monitoring and Assessment of Land Use and Land Cover Changes (1977-2010) In Kamrup District of Assam, India Using Remote Sensing and Gis Techniques. Applied Ecology and Environmental Research. 15 (3), 221-239.

Kumruzzaman M. and Sarker A. (2017). Water requirements for various crops and impact of irrigation in barind area. Malaysian Journal of Sustainable Agriculture. 1(1), 04-07.

Kylili A., Fokaides P.A., Ioannides A., Kalogirou S. (2018). Environmental assessment of solar thermal systems for the industrial sector. Journal of Cleaner Production. 176, 99-109. DOI: 10.1016/j.jclepro.2017.12.150.

Mi C., Zhang Z.W. and Huang Y.F. 2016. A Fast-Automated Vision System for Container Corner Casting Recognition. Journal of Marine Science and Technology. 24 (1), 54-60.

Minkov L., Krokhina A. and Dueck I. (2011). Discharge characteristics of a hydrocyclone with built-in injector. Thermophysics and Aeromechanics. 18 (3), 397-409.
Nema A., Yadav K.D. and Christian R.A. (2017). Effect of retention time on primary media for greywater treatment. Water Conservation and Management. 1 (1), 01-03.

Olatuyi S., Kumaragamage D. and Akinremi O. (2014). Heavy-metal fractions in solid and liquid separates of swine slurry separated using different technologies. Journal of Environmental Quality. 43 (5), 1779-1789.

Otto N., Platz S. and Fink T. (2016). Removal of micropollutants with coarse-ground activated carbon for enhanced separation with hydrocyclone classifiers. Water Science and Technology. 73 (11), 2739-2746.

Park K., Lee J., Bae B., Kim Y.H. and Choung Y.K. (2006). Use of hydrocyclone and flotation column for reducing the volume of contaminated dredged material. Water Science and Technology. 53 (6), 151-157.

Ramezani M.R., Bavani A.R.M., Jafari M. and Binesh A. (2017). Evaluating gridded BIOME-BGC for simulating LAI at Kasilian watershed-Iran. Geology, Ecology, and Landscapes. 1(4), 225-231.

Rehman R., Khan A., Rashid H. and Nasir A. (2017). Performance Evaluation of Fly Ash and Red Brick Dust for Recovery of Chromium from Tannery Wastewater by Adsorption Method. Earth Science Pakistan. 1(1), 21-24.

Shadrunova I. and Orekhova N. (2015). A process for advanced recycling of water originating from mining operations with metal recovery. Mine Water Environment. 4 (4), 478-484.

Shahrabi F., Yaghmaei S. and Mousavi S. (2014). Bioleaching of heavy metals from a petroleum spent catalyst using acidithiobacillus thiooxidans in a slurry bubble column bioreactor. Separation and Purification Technology. 132, 41-49.

Sharma D. and Yadav K.D. (2017). Vermicomposting of Flower Waste: Optimization of Maturity Parameter by Response Surface Methodology. Malaysian Journal of Sustainable Agriculture. 1(1), 15-18.

Sierra C., Gallego J. and Afif E. (2013). Analysis of soil washing effectiveness to remediate a brownfield polluted with pyrite ashes. Journal of Hazardous Materials. 180 (1), 602-608.

Singh A., Kewat M.L. and Sondhia S. (2018). Studies on the effect of day time application of herbicide mesosulfuronmethyl on soil microbial communities of wheat rhizosphere. Journal of Environmental Biology. 39 (1), 59-65. DOI: $10.22438 / \mathrm{jeb} / 39 / 1 / \mathrm{MRN}-562$.

Tang B., Xu Y., Song X., Sun Z. and Yu J. (2015). Numerical study on the relationship between high sharpness and configurations of the vortex finder of a hydrocyclone by central composite design. Chemical Engineering Journal. 278, 504-516. 
Teng Y. and Zhou Q. (2017). Environmental effect of Sudan I-IV: adsorption behaviours and potential risk on soil. Acta Scientifica Malaysia. 1(1), 16-17.

Uddina A.B.M.H., Alaamaa M., Zaidul I.S.M., Abbasb S.A., Awang M. and Fahim T.K. (2017). Current analytical methods for amlodipine and its formulations: a review. Journal CleanWAS. 1 (1), 17-22.

Usman M., Yasin H., Nasir D.A. and Mehmood W. (2017). A Case Study of Groundwater Contamination Due to Open Dumping of Municipal Solid Waste in Faisalabad, Pakistan. Earth Sciences Pakistan. 1 (2), 12-13.

Usman M., Yasin H., Rashid H. and Nasir A. (2017). Quantification of $\mathrm{CO}_{2}$ Emissions from Vehicles and Possible Remedial Strategies in Faisalabad City. Earth Science Pakistan. 1(1), 17-20.

Vazdani S., Sabzghabaei G., Dashti S., Cheraghi M., Alizadeh R. and Hemmati A. (2017). Fmea Techniques Used in Environmental Risk Assessment. Environment Ecosystem Science. 1 (2), 16-18.

Yang A., Han Y., Pan Y., Xing H. and Li J. (2017). Optimum surface roughness prediction for titanium alloy by adopting response surface methodology. Results in Physics. 7, 1046-1050.

DOI: 10.1016/j.rinp.2017.02.027.
Yang Y., Zhong M., Yao H., Yu F. and Fu X. and Postolache O. (2018). Internet of Things for Smart Ports: Technologies and Challenges. IEEE Instrumentation \& Measurement Magazine. 21 (1), 34-43.

Yasin H. and Usman M. (2017). Site investigation of open dumping site of Municipal Solid Waste in Faisalabad. Earth Science Pakistan. 1 (1), 25-27.

Yun G., Williams S. and Wenbin D. (2017). Water management of the Mekong river. Water Conservation and Management. 1 (2), 10-12.

Zaidi N.A., Hamid A.A.A. and Hamid H.A. (2017). Lactic acid bacteria with antimicrobial properties isolated from the instestines of japanese quail (Coturnix Coturnix Japonica). Science Heritage Journal. 1(1), 10-12.

Zhang J., You X. and Niu Z. (2011) Numerical simulation of solid-fluid flow in hydrocyclone. Chemical and Biochemical Engineering. 25 (1), 37-41. 